\title{
Use of ProSeal Laringeal Mask Airway Under Bronchoscopy Guidance During Percutaneous Dilatational Tracheostomy
}

\section{Perkütan Dilatasyonel Trakeostomi Sırasında Bronkoskopi Rehberliğinde ProSeal Laringeal Maske Kullanımı}

\author{
Eylem Yasar ${ }^{1}$, Ezgi Donmez ${ }^{2}$, Semra Gumus Demirbilek ${ }^{3}$ \\ ${ }^{1}$ Mugla Sitki Kocman Training and Research Hospital, Clinic of Anesthesiology and Reanimation, Mugla, Turkey \\ ${ }^{2}$ Yatagan State Hospital, Clinic of Anesthesiology and Reanimation, Mugla, Turkey \\ ${ }^{3}$ Mugla Sitki Kocman University Faculty of Medicine, Department of Anesthesiology and Reanimation, Mugla, Turkey
}

\section{ABSTRACT}

Objective: In the current study, our primary aim is to compare complication rates between using ProSeal laryngeal mask airway (P-LMA) and endotracheal tube (ETT) in bronchoscopy-guided percutaneous dilatational tracheostomy (PDT) procedure. Our secondary aim is to compare the processing time of these two techniques.

Methods: Sixty-one adult patients who were intubated in the intensive care unit and scheduled for PDT due to the need for long-term mechanical ventilation were included in the study. The patients were randomly divided into ETT group or P-LMA group under bronchoscopy guidance. Complications related to the procedures and the duration of each procedure were recorded. Hemodynamic measurements, oxygen saturation, arterial blood gas analysis, preferred mechanical ventilation mode, positive end expiratory pressure and mean airway pressure values were recorded before PDT, and 30 minutes after the procedure.

Results: A total of 61 cases, 23 (38\%) female and 38 (62\%) male, participated in the study. Regarding the complication rates between the groups, we encountered more complications in the ETT group and the most common complication was puncture of the cuff of the intubation tube. The procedure time was also significantly shorter in the P-LMA group (P-LMA; 2.5 min, ETT; 3.6 $\min )$.

Conclusion: Using P-LMA for PDT under bronchoscopy caused lower complication rate than using ETT. In a addition the duration of PDT procedure was shorter in P-LMA group than ETT group.

Keywords: Percutaneous dilatational tracheostomy, bronchoscopy, laryngeal mask

\section{öz}

Amaç: Bu çalışmada birincil amacımız, bronkoskopi eşliğinde perkütan dilatasyonel trakeostomi (PDT) işleminde ProSeal laringeal maske (P-LMA) ve endotrakeal tüp (ETT) kullanımı arasındaki komplikasyon oranlarını karşılaştırmaktır. İkincil amacımız ise bu iki tekniğin işlem sürelerini karşılaştırmak.

Yöntem: Çalışmaya, yoğun bakım ünitesinde entübe edilen ve uzun süreli mekanik ventilasyon ihtiyacı nedeniyle PDT planlanan 61 erişkin hasta dahil edildi. Hastalar rastgele ETT grubuna veya bronkoskopi rehberliğinde P-LMA grubuna ayrıldı. İşlemlere ilişkin komplikasyonlar ve her işlemin süresi kaydedildi. Perkütan dilatasyonel trakeostomi öncesi ve işlemden 30 dakika sonraki hemodinamik ölçümler, oksijen satürasyonu, arter kan gazı analizi, tercih edilen mekanik ventilasyon modu, pozitif end ekspiratuar basınç ve ortalama hava yolu basıncı değerleri kaydedildi.

Bulgular: Çalışmaya 23 (\%38) kadın ve 38 (\%62) erkek olmak üzere toplam 61 olgu katıldı. Gruplar arası komplikasyon oranlarına bakıldığında, ETT grubunda daha fazla komplikasyonla karşılaştik ve en sık karşılaşılan komplikasyon entübasyon tüpünün kafinın delinmesi idi. İşlem süresi de P-LMA grubunda anlamlı olarak daha kısaydı (P-LMA; 2,5 dak, ETT; 3,6 dak).

Sonuç: Bronkoskopi eşliğinde yapılan perkütan dilatasyonel trakeostomi işleminde P-LMA ve ETT kullanımını karşılaşttrdığımız çalışmamızda P-LMA grubunda entübasyona oranla komplikasyon oranının daha az olduğu, işlem süresinin daha kısa olduğu bulunmuştur.

Anahtar sözcükler: Perkütan dilatasyonel trakeostomi, bronkoskopi, laringeal maske
Received/Geliş tarihi : 23.06 .2021 Accepted/Kabul tarihi : 13.10 .2021 Publication date

: 28.01.2022
*Corresponding author: Eylem Yasar • eylemtarakci@gmail.com

Eylem Yasar 두 0000-0002-5144-3077 / Ezgi Donmez ำ 0000-0002-5381-6375

Semra Gumus Demirbilek (1) 0000-0001-7721-4582

Cite as: Yasar E, Donmez E, Gumus Demirbilek S. Use of proseal laringeal mask airway under bronchoscopy guidance during percutaneous dilatational tracheostomy. JARSS 2022;30(1):9-15. 


\section{INTRODUCTION}

Tracheostomy is routinely performed in patients in the intensive care unit (ICU) to prevent complications related to endotracheal intubation (1). The use of percutaneous dilatation in a tracheostomy was first described in 1957. However, there is risk in complications during this PDT procedures.

These include cardiopulmonary arrest, bleeding, tube obstruction, pneumothorax, pneumomediastinum, aspiration pneumonia, posterior wall lesions, tracheal ring fractures, tube malpositioning and subcutaneous emphysema. About $10 \%$ of PDT-related complications are the result of difficulties in placing the tracheostomy tube. These complications include bursting of the cuff of the endotracheal tube (ETT), which can cause aspiration and an increased frequency of pneumonia, as well as the needle inserted into the trachea ring the ETT and the guidewire passing through the Murphy Eye, leading to accidental extubation or unilateral intubation, depending on the location of the ETT (2-7). With the aid of fiberoptic bronchoscopy, complications that may arise can be prevented as airway visualization provides a better view (8).

In PDT, a tracheal tube is generally used for airway management. Before inserting the needle into the trachea, the cuff of the intubation tube is deflated, and the cuff is pulled back to the vocal cords (9). At this stage of the procedure, the tracheal tube is not fixed inplace, and it may be dislodged, causing loss of airway and aspiration. During PDT, the use of a classic laryngeal mask airway (LMA) device for ventilation can prevent the accidental failure of ventilation due to removal of the intubation tube, as well as many tube-related complications (10). Some studies reported that replacing ETT with LMA during the PDT procedure lead to a better protected airway, improved visualization of the larynx, provide a better airway and improved ventilation in many patients $(5,10,11)$. It is also known that reported studies done with bronchoscopy during the PDT procedure aided visualization of the trachea and positioning of the guide wire $(5,6,12-16)$. The primary goal of this study was to compare complications in PDT procedures using an ETT and a ProSeal-LMA (P-LMA) under guidance of bronchoscopy. The secondary aim is to compare the time required for the tracheostomy procedure between the two groups.

\section{MATERIAL and METHODS}

The study was conducted in a randomized, controlled manner in a university hospital after receiving approval from the institution's ethical committee (local ethics committee date; 10.06.2016, number; 16/VII, Clinical Trial number; NCT04637932). The study was conducted by the principles described in the Declaration of Helsinki. The first participant registered on 15.06.2016. The study included patients over the age of 18 who had been intubated in the ICU for a long time and were scheduled for PDT due to a suspicion of a longterm requirement for mechanical ventilation treatment. The study excluded patients having a history of cervical trauma, high-pressure mechanical ventilation (i.e., inspiratory pressure greater than $40 \mathrm{~cm} \mathrm{H}_{2} \mathrm{O}$ ), pulmonary oedema, or severe respiratory distress. All the PDT procedures were performed by an anaesthesiology and intensive care specialist physician and a fourth-year research assistant.

The required sample size was determined by performing a power analysis using a chi-square table. The lowest complication rate in previous studies was $10-15 \%(17,18)$. To obtain significance of $\alpha=0.05$ and $80 \%$ power $(1-\beta=0.8)$, the required size of the sample in each group was at least 29 . The final study included 61 patients.

Patients were randomized into two groups using computer-based randomization: 61 patients completed the study, 30 in the ETT group and 31 in the P-LMA group. The patients in both groups fasted for 6 hours before the procedures and were monitored as standard, according to the recommendations of the American Society of Anesthesiology (19). Inspired oxygen (100\%) was administered for 15 minutes before each procedure. Sedation was achieved by propofol (100-200 $\mu \mathrm{g}$ $\mathrm{kg}^{-1}$ ), and muscle relaxation was preffered by rocuronium (0.6 $\mathrm{mg} \mathrm{kg}{ }^{-1}$ ). In the ETT group, a pillow was placed beneath the patient's shoulders, and the patient's neck was placed in the extended position. The cuff of the tracheal tube was retracted, so that it was visible between the vocal cords. The neck area was cleaned with $10 \%$ polyvidone iodine and covered with sterile drapes. Then, $5 \mathrm{~mL}$ of $2 \%$ lidocaine was infiltrated subcutaneously into the $2^{\text {nd }}$ and $3^{\text {rd }}$ tracheal rings. The skin was then incised using a $1 \mathrm{~cm}$ vertical incision. The location of the needle was confirmed by placing $2-3 \mathrm{~mL}$ of saline solution in the trachea from the median line and aspirating the air. After the guide wire was advanced through the needle, the tracheostomy cannula was placed into the tracheal lumen and the cuff of the cannula was inflated.

In the P-LMA group, the endotracheal tube was replaced with a P-LMA (number 4 for female patients and number 5 for male patients) before the procedure, and the cuff was inflated. Ventilation, adequate chest movement and expiratory tidal volume were confirmed by minimal leakage around the cuff and stable vital signs. Then, as in the ETT group, the patient was positioned by placing a pillow under the shoulders. The patient's neck was then sterilized and lidocaine was applied to skin-subcutaneous tissue at the level of the tracheal 2-3 rings. Before proceeding further, tracheal canal was visualized by advancing the fiberoptic bronchoscope through the P-LMA. All other steps in the procedure were performed under the visual guidance of a bronchoscope. 
As standard, the The Acute Physiology and Chronic Health Evaluation (APACHE) II and The sequential organ failure assessment score (SOFA) scores of all patients at the time of entry to the ICU were calculated. Hemodynamic measurements, oxygen saturation, arterial blood gas analysis, end tidal carbondioxide, preferred mechanical ventilation mode, positive end expiratory pressure and other airway pressure values before each procedure, 30 minutes after each procedure and also the duration of the procedures were recorded. Hemodynamic measurements were recorded before the PDT procedure and every 5 minutes until 30 minutes after processing completion. In addition, complications such as length of the procedure and unsuccessful LMA insertion, unsuccessful tracheal puncture, guide misplacement, difficult insertion or failure to insert the tracheostomy cannula were observed.

\section{Statistical Analysis}

The statistical analysis was performed using SPSS Statistics for Windows, version 16.0 (IBM Corp., Armonk, NY). Mean and standard deviation are used to present descriptive data. The distribution of the data were analysed by the ShapiroWilk test. The T test was employed to determine the data's normality. The Mann-Whitney $U$ test was employed for non-normally distributed data. For categorical variables, the chi-square test was used, and univariate analysis was used to investigate the effects of multiple categorical variables on continuous dependent numerical variables. Multivariate test was applied for before-after comparison within the group. In all statistical analyses, a $p$ value of $<0.05$ was considered statistically significant.

\section{RESULTS}

A total of sixty-one patients, 26 females and 35 males, scheduled to undergo the PDT procedure, were divided into two ETT and P-LMA groups (Figure 1). In terms of there was no significant difference between the age $(p=0.0069)$, gender $(p=0.247)$, weight $(p=0.906)$ and height $(p=0.688)$ of the patients in the ETT and P-LMA groups (Table I). There was no significant difference between groups in the APACHEII $(p=0.893)$ and SOFA ( $p=0.051)$ scores. The positive end-expiratory pressure (PEEP) values of patients were $7.03( \pm 2.40)$ in the ETT group, and $6.55( \pm 1.89)$ in the P-LMA group, with no statistically significant difference $(p=0.546)$ (Table II). The time taken to perform to tracheostomy; $3.6( \pm 2.6) \mathrm{min}$ in the ETT group and $2.5( \pm 1.6) \mathrm{min}$ in the P-LMA group. Thus, the procedure time in the P-LMA group was significantly shorter than that in the ETT group (Table II).

When the rates of all complication in the two groups were compared, the ETT group had a significantly higher rate than

\section{ICU patients scheduled for percutaneous} dilatational tracheostomy (PDT) $(n=61)$

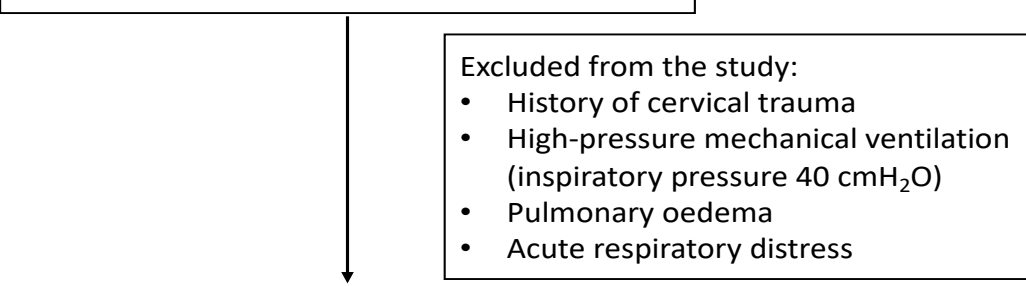

Patients were randomly divided into 2 groups for airway management to be used during PDT

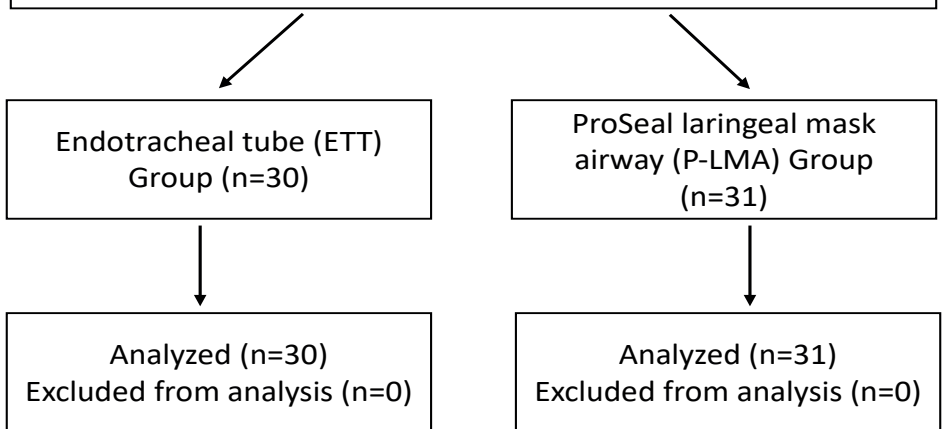

Figure 1: Study flow chart. 
the P-LMA group $(p=0.041)$ (Table III). The most common complication was ETT cuff puncture in the ETT group with a rate of $18.03 \%$. Difficult insertion of tracheostomy tube was the second most common with a rate of $3.28 \%$, and it was seen in the ETT group. Other complications were bleeding, subcutaneous emphysema, guide's passing through the Murphy's Eye, bronchospasm and failure to place the LMA.

Table I: Demographic Characteristics of the Groups

\begin{tabular}{lccc} 
& $\begin{array}{c}\text { ETT group } \\
(\mathbf{n}=\mathbf{3 0})\end{array}$ & $\begin{array}{c}\text { P-LMA group } \\
(\mathbf{n = 3 1 )}\end{array}$ & $\mathbf{p}$ \\
\hline Age (years) & $66.10 \pm 9.82$ & $64.97 \pm 19.78$ & 0.006 \\
\hline Weight $(\mathrm{kg})$ & $77.00 \pm 20.99$ & $74.93 \pm 8.37$ & 0.906 \\
\hline Height $(\mathrm{cm})$ & $168.47 \pm 9.30$ & $167.22 \pm 9.20$ & 0.688 \\
\hline $\begin{array}{l}\text { Sex (Female) } \\
\text { male) }\end{array}$ & $11 / 19$ & $15 / 16$ & 0.247
\end{tabular}

*Results are expressed as mean \pm standard deviation or number of patients.

Table II: Comparison of APACHE II, SOFA, PEEP and PDT Processing Time Between Groups

\begin{tabular}{lccc} 
& $\begin{array}{c}\text { ETT group } \\
(\mathbf{n}=\mathbf{3 0})\end{array}$ & $\begin{array}{c}\text { P-LMA group } \\
(\mathbf{n}=\mathbf{3 1})\end{array}$ & $\mathbf{p}$ \\
APACHE II & $27.87 \pm 11.22$ & $32.16 \pm 14.96$ & 0.893 \\
\hline SOFA & $11.10 \pm 4.80$ & $10.48 \pm 3.26$ & 0.051 \\
\hline PEEP & $7.03 \pm 2.40$ & $6.55 \pm 1.89$ & 0.546 \\
\hline $\begin{array}{l}\text { PDT processing } \\
\text { time (min) }\end{array}$ & $3.6 \pm 2.6$ & $2.5 \pm 1.6$ & 0.044 \\
\hline
\end{tabular}

APACHE II: Acute physiology and chronic health evaluation, SOFA: Sequential organ failure assessment score, PEEP: Positive end-expiratory pressure, PDT: Percutaneous dilatation tracheostomy.

*Results are expressed as mean \pm standard deviation.

Table III: Comparison of Complication Rates Between Groups

\begin{tabular}{|c|c|c|}
\hline Complications & $\begin{array}{l}\text { ETT group } \\
(n=30)\end{array}$ & $\begin{array}{l}\text { P-LMA group } \\
\quad(n=31)\end{array}$ \\
\hline ETT cuff puncture & $11(18.03 \%)$ & - \\
\hline $\begin{array}{l}\text { Difficult insertion of } \\
\text { tracheostomy tube }\end{array}$ & $2(3.28 \%)$ & $6(9.84 \%)$ \\
\hline Bleeding & $3(4.92 \%)$ & $2(3.28 \%)$ \\
\hline Subcutaneous emphysema & - & $1(1.64 \%)$ \\
\hline $\begin{array}{l}\text { Guidewire passing through } \\
\text { Murphy's Eye }\end{array}$ & $3(4.92 \%)$ & - \\
\hline Bronchospasm & - & $1(1.64 \%)$ \\
\hline LMA cannot be placed & - & $1(1.64 \%)$ \\
\hline Total complication rate & $19(31.15 \%)$ & $11(18.03 \%)$ \\
\hline
\end{tabular}
did not differ significantly between the two groups. At the same time, desaturation was not experienced in any of our patients.

In the blood gas analysis (BGA) of the patients in the ETT group, there was no significant difference in partial pressure of oxygen $\left(\mathrm{pO}_{2}\right)$, partial pressure of carbon dioxide $\left(\mathrm{pCO}_{2}\right)$, or lactate values before and after the PDT procedure $(p>0.05)$. After the PDT procedure, the $\mathrm{pH}$ and $\mathrm{HCO}_{3}$ levels in the ETT group were low $(p=0.040$ and $p=0.007$, respectively (Table IV). The mean airway pressure (Pmean) and peak airway pressure (Ppeak) values were also low post-PDT in the ETT group ( $p=0.043$ and $p=0.003$, respectively) (Table IV).

The arterial blood gas values of patients in the P-LMA group did not differ significantly before and after PDT $(p>0.05)$. (Table V).

In order to evaluate the method used during the PDT procedure, the airway pressure (Paw) value, which is one of the mechanical ventilation parameters recorded in correlation with the arterial blood gas at the $30^{\text {th }}$ minute after the procedure, was significantly lower $(p=0.023)$. There was no difference in the $\mathrm{ETCO}_{2}, \mathrm{pO}_{2} /$ fraction of inspired oxygen (P/F) ratio, Peak inspiratory pressure $\left(\mathrm{P}_{\mathrm{IP}}\right)$ or peripheral oxygen saturation $\left(\mathrm{SpO}_{2}\right)$ values before or after the PDT procedure (Table V).

\section{DISCUSSION}

We investigated the effects by using P-LMA or ETT for PDT performed with bronchoscopy on complications and duration of the procedure. There are so many complications such as ETT

Table IV: Comparison of Data Before and After Tracheostomy in the ETT Group

\begin{tabular}{lccc} 
& Before PDT & After PDT & $p$ \\
\hline $\mathrm{PaO}_{2}(\mathrm{mmHg})$ & $96.32 \pm 22.28$ & $113.67 \pm 67.68$ & 0.200 \\
\hline $\mathrm{pH}$ & $7.46 \pm 0.08$ & $7.44 \pm 0.08$ & 0.040 \\
\hline $\mathrm{PaCO}_{2}(\mathrm{mmHg})$ & $41.27 \pm 9.48$ & $41.73 \pm 8.94$ & 0.562 \\
\hline $\mathrm{HCO}_{3}\left(\mathrm{mEq} \mathrm{L}^{-1}\right)$ & $29.17 \pm 5.39$ & $28.43 \pm 4.88$ & 0.007 \\
\hline Lactate $\left(\mathrm{mmol} \mathrm{L}^{-1}\right)$ & $1.25 \pm 0.93$ & $1.25 \pm 0.93$ & 0.910 \\
\hline $\mathrm{P} / \mathrm{F} \mathrm{ratio}$ & $271.90 \pm 128.88$ & $264.53 \pm 101.02$ & 0.007 \\
\hline $\mathrm{Paw}\left(\mathrm{cmH}_{2} \mathrm{O}\right)$ & $11.51 \pm 4.08$ & $10.57 \pm 3.76$ & 0.043 \\
\hline $\mathrm{P}_{\mathrm{IP}}\left(\mathrm{cmH}_{2} \mathrm{O}\right)$ & $22.93 \pm 6.89$ & $21.27 \pm 7.15$ & 0.003 \\
\hline $\mathrm{sPO}(\%)$ & $96.67 \pm 3.06$ & $97.00 \pm 3.19$ & 0.366 \\
\hline
\end{tabular}

${ }^{*} \mathrm{PaO}_{2}$ : Partial pressure of oxygen, $\mathrm{pH}$ : Potential of hydrogen, $\mathrm{PaCO}_{2}$ : Partial pressure of carbon dioxide, $\mathrm{HCO}_{3}$ : Bicarbonate, $\mathrm{P} / \mathrm{F}$ ratio: $\mathrm{PaO}_{2} /$ $\mathrm{FiO}_{2}$, Paw: Airway pressure, $\boldsymbol{P}_{1 \mathrm{P}}$ : Peak inspiratory pressure, $\mathbf{S P O}_{2}$ : Oxygen saturation, PDT: Percutaneous dilatational tracheostomy. 
Table V: Comparison of Data Before and After Tracheostomy in the P-LMA Group

\begin{tabular}{lccc} 
& Before PDT & After PDT & $p$ \\
$\mathrm{PaO}_{2}(\mathrm{mmHg})$ & $96.32 \pm 22.28$ & $122.48 \pm 86.27$ & 0.108 \\
\hline $\mathrm{pH}$ & $7.49 \pm 0.08$ & $7.47 \pm 0.09$ & 0.286 \\
\hline $\mathrm{paCO}_{2}(\mathrm{mmHg})$ & $45.90 \pm 10.17$ & $46.87 \pm 11.53$ & 0.600 \\
\hline $\mathrm{HCO}_{3}\left(\mathrm{mEq} \mathrm{L}^{-1}\right)$ & $32.98 \pm 5.30$ & $32.84 \pm 5.56$ & 0.681 \\
\hline Lactate $\left(\mathrm{mmol} \mathrm{L}^{-1}\right)$ & $1.16 \pm 1.10$ & $0.74 \pm 0.71$ & 0.361 \\
\hline $\mathrm{ETCO}_{2}(\mathrm{mmHg})$ & $47.23 \pm 10.02$ & $48.03 \pm 12.20$ & 0.649 \\
\hline $\mathrm{P} / \mathrm{F} \mathrm{ratio}$ & $260.45 \pm 16.66$ & $269.39 \pm 20.85$ & 0.658 \\
\hline $\mathrm{Paw}\left(\mathrm{cmH}_{2} \mathrm{O}\right)$ & $11.87 \pm 3.33$ & $11.05 \pm 2.80$ & 0.023 \\
\hline $\mathrm{P}_{\mathrm{IP}}\left(\mathrm{cmH}_{2} \mathrm{O}\right)$ & $22.19 \pm 1.37$ & $22.19 \pm 1.27$ & 0.330 \\
\hline $\mathrm{sPO}(\%)$ & $96.68 \pm 2.12$ & $96.94 \pm 1.73$ & 0.502 \\
\hline
\end{tabular}

${ }^{*} \mathrm{ETCO}_{2}$ : End-tidal carbon dioxide, $\mathrm{PaO}_{2}$ : Partial pressure of oxygen, pH: Potential of hydrogen, $\mathrm{PaCO}_{2}$ : Carbon dioxide, $\mathrm{HCO}_{3}$ : Bicarbonate; $P / F$ ratio: $\mathrm{PaO} / \mathrm{FiO}_{2}$, Paw: Airway pressure, $\boldsymbol{P}_{I P}$ : Peak inspiratory pressure, sPO $P_{2}$ Oxygen saturation; PDT: Percutaneous dilatational tracheostomy.

cuff puncture, difficult insertion of tracheostomy tube, bleeding, subcutaneous emphysema, guidewire passing through Murphy's Eye, bronchospasm and unplaceable LMA during tracheostomy procedure. We found that the frequency of complications was less and the duration of the intervention was short in the P-LMA group. We found that the frequency of overall complication incidence was lower (18.03\% versus $31.15 \%)$ and the period of the operation time was shorter in the P-LMA group ( $2.5 \mathrm{~min}$ versus $3.6 \mathrm{~min}$ ).

A tracheostomy is commonly performed in patients who are predicted to require prolonged mechanical ventilation in the ICU $(2,3,20)$. The tracheostomy procedure enables access to the airway, cleaning of pulmonary secretions, communication with the patient and oral nutrition $(5,16,20,21)$. Studies which reported the comparison between PDT procedures with percutaneous and surgical techniques, it was found that the procedure time was shorter and bleeding and postoperative complications were encountered less with the PDT procedure (20-23).

Dosemeci et al., in their study comparing fiberoptic-guided LMA and ETT during the PDT procedure, reported that the procedure time was shorter in the LMA group $(4.5 \mathrm{~min}$ in the LMA group, 5.9 min in the ETT group (5). Similarly, Linstedt et al. reported a shorter procedure time in the LMA group (11 min in the LMA group, 13 min in the ETT group) (15). In our study, it was observed that the processing time was shorter in the PDT procedure. We think that this difference is due to the fact that the team performing the procedure is experienced in PDT.
Reported disadvantages of the LMA include difficulty placing the device, insufficient ventilation and increased intracranial pressure as a result of acidosis and hypercarbia (23). In our study, orotracheal re-intubation was required in one patient in the P-LMA group due to difficulties placing the LMA. Any problems were encountered in terms of ventilation and hemodynamics in this patient. In our study, the overall complication rate in the P-LMA group was $18.03 \%$, while in the ETT group it was $31.15 \%$. Ambesh et al. reported a cuff puncture rate of $6.6 \%$ and incidence of unintentional extubation of $3.3 \%(16)$. Karimpour et al. reported a cuff puncture rate of $1.1 \%$ and airway loss of $1.1 \%$ (17). In our study, tube-related complications developed in 19 patients $(31.15 \%)$ and cuff puncture occurred in 11 (18.03\%) patients. In our study, while 19 patients developed tube-related complications in the ETT group, 11 (18.03\%) patients had cuff puncture. Guidewire passed through Murphy's Eye of intubation tube in $3(4.92 \%)$ patients. Compared to the reported complication rates in the literature, tube-related complications rate were relatively high in our study. In our study, the most common complication in the ETT group was cuff puncture (18.03\%). In our study, there was a low incidence of bleeding, with bleeding occurring in $4.92 \%$ of patients in the ETT group and $3.28 \%$ of patients in the P-LMA group. We consider that use of the LMA could prevent these complications. Saritas et al. concluded that the routine use of fiberoptic bronchoscopy during PDT is not necessary, but it may be beneficial for obese patients and patients with difficult neck anatomy (8). In our study, complications developed in 11 (18.03\%) patients in the P-LMA group. The most common complication was difficult insertion of the tracheostomy tube into the tracheal lumen in $6(9.84 \%)$ patients. Minor bleeding occurred in 2 patients $(3.28 \%)$ in the ETT group and it was stopped with local interventions. During the PDT procedure, one $(1.64 \%)$ patient in the P-LMA group developed bronchospasm. These patients showed a rapid response to bronchodilator therapy and did not develop permanent damage. Subcutaneous emphysema developed in one (1.64\%) patient the P-LMA group on the first post-operative day. It is stated that subcutaneous emphysema may develop due to extreme cough and tissues in the stoma around the trachesotomy (24). In our patient, subcutaneous emphysema volume and size was low and dissappear on the $7^{\text {th }}$ day. The LMA could not be placed in one (1.64\%) patient, and the PDT procedure was performed again by orotracheal intubation. We attribute the lower complication rate in the P-LMA group to the use of the LMA and bronchoscopy together. This allowed visualization of the anatomy of the larynx, the needle entering the trachea, the passage of the guidewire, and the entry of the dilatator into the tracheal canal. The use of the LMA and bronchoscopy together also made it easier to control the position of the cannula. Reilly et al. reported that $\mathrm{PaCO}_{2}$ pressure increased during the PDT 
procedure under the guidance of bronchoscopy in patients ventilated with an endotracheal tube (23). In their study, the duration of the PDT was $13 \pm 6 \mathrm{~min}$. In our study, it was $3.6( \pm 2.6) \mathrm{min}$ in the ETT group and $2.5( \pm 1.6)$ minute in the P-LMA group. Partial $\mathrm{CO}_{2}$ pressure did not increase in present study and we attribute this to the shorter bronchoscopy time as compared with that reported in the study by Reilly et al. (23). In our study, there was a statistically significant decrease in PIP level after tracheostomy compared to pre-tracheostomy values in the ETT group. This finding indicates that the pressure decreased after the PDT procedure. The change in Paw pressure and that the pressure decreased after the PDT procedure. In this situation, lung ventilation improved in both groups after tracheostomy.

\section{CONCLUSION}

The use of bronchoscopy, together with the LMA, can help to eliminate posterior wall trauma by providing visualisation of tracheal lumen during the procedure.

Using P-LMA under bronchoscopy instead of ETT for PDT resulted in a decreased complication rate. Additionally, the PDT technique took less time in the P-LMA group than in the ETT group.

\section{AUTHOR CONTRIBUTIONS}

\section{Conception or design of the work: $E Y$}

Data collection: EY, SGD, ED

Data analysis and interpretation: EY, ED, SGD

Drafting the article: $E Y, E D, S G D$

\section{Critical revision of the article: $E Y, E D, S G D$}

All authors (EY, ED, SGD) reviewed the results and approved the final version of the manuscript.

\section{REFERENCES}

1. Kastanos N, Estopa Miro R, Marin Perez A, Xaubet Mir A, Agusti-Vidal A. Laryngotracheal injury due to endotracheal intubation: Incidence, evolution, and predisposing factors. A prospective long-term study. Crit Care Med 1983;11(5): 3627.

2. Marelli D, Paul A, Manolidis S, et al. Endoscopic guided percutaneous tracheostomy: Early results of a consecutive trial. J Trauma 1990;30(4):433-5.

3. Kearney PA, Griffen MM, Ochoa JB, Boulanger BR, Tseui BJ, Mentzer Jr RM. A single- center 8-year experience with percutaneous dilational tracheostomy. Ann Surg 2000;231(5):701-9.
4. El-Naggar $M$, Sadagopan S, Levine $H$, Kantor H, Collins VJ. Factors influencing choice between tracheostomy and prolonged translaryngeal intubation in acute respiratory failure: A prospective study. Anesth Analg 1976;55(2):195201.

5. Dosemeci L, Yilmaz M, Gürpinar F, Ramazanoglu A. The use of the laryngeal mask airway as an alternative to the endotracheal tube during percutaneous dilatational tracheostomy. Intensive Care Med 2002;28(1):63-7.

6. Strametz R, Bergold MN, Weberschock T. Laryngeal mask airway versus endotracheal tube for percutaneous dilatational tracheostomy in critically ill adults. Cochrane Database of Syst Rev, 2018 Nov 15. doi: 10.1002/14651858. CD009901.pub3 [Epub ahead of print].

7. Price GC, McLellan S, Paterson RL, Hay A. A prospective randomised controlled trial of the LMA Supreme vs cuffed tracheal tube as the airway device during percutaneous tracheostomy. Anaesthesia 2014;69(7):757-63.

8. Saritas A, Saritas PU, Kurnaz MM, Beyaz SG, Ergonenc T. The role of fiberoptic bronchoskopy monitoring during percutaneous dilatational tracheostomyand its routine use into tracheotomy practice. J Pak Med Assoc 2016;66(1): 83-9.

9. Ciaglia P, Firsching R, Syniec C. Elective percutaneous dilatational tracheostomy: A new simple bedside procedure; preliminary report. Chest 1985;87(6):715-9.

10. Sarkar S, Shashi P, Paswan AK, Anupam RP, Suman S, Dube SK. Use of the proseal laryngeal mask airway facilitates percutaneous dilatational tracheostomy in an intensive care unit. Indian J Crit Care Med 2010;14(4):185-7.

11. Dexter TJ. The laryngeal mask airway: A method to improve visualisation of the trachea and larynx during fibreoptic assisted percutaneous tracheostomy. Anaesth Intensive Care 1994;22(1):35-9.

12. Sohrt A, Ehlers L, Udsen FW, Maerkedahl A, McGrath BA. Cost comparison of single-use versus reusable bronchoscopes used for percutaneous dilatational tracheostomy. Pharmacoecon Open 2019;3(2):189-95.

13. Iftikhar IH, Teng S, Schimmel M, Duran C, Sardi A, Islam S. A network comparative meta analysis of percutaneous dilatational tracheostomies using anatomic landmarks, bronchoscopic, and ultrasound guidance versus open surgical tracheostomy. Lung 2019;197(3):267-75.

14. Shen G, Yin H, Cao Y, et al. Percutaneous dilatational tracheostomy versus fibre optic bronchoscopy-guided percutaneous dilatational tracheostomy in critically ill patients: A randomised controlled trial. Ir J Med Sci 2019;188(2):675-81. 
15. Linstedt U, Zenz M, Krull K, Häger D, Prengel AW. Laryngeal mask airway or endotracheal tube for percutaneous dilatational tracheostomy: A comparison of visibility of intratracheal structures. Anesthesia \& Analgesia 2010;110: 1076-82.

16. Ambesh SP, Sinha PK, Tripathi M, Matreja P. Laryngeal mask airway vs endotracheal tube to facilitate bedside percutaneous tracheostomy in critically ill patients: A prospective comparative study. J Postgrad Med 2002;48(1):11-5.

17. Karimpour HA, Vafaii K, Chalechale M, Mohammadi S, Kaviannezhad R. Percutaneous dilatational tracheostomy via Griggs technique. Arch Iran Med 2017;20(1):49-54.

18. Verghese C, Rangasami J, Kapila A, Parke T. Airway control during percutaneous dilatational tracheostomy: Pilot study with the intubating laryngeal mask airway. $\mathrm{Br} J$ Anaesth 1998;81(4):608-9.

19. Heffner JE. The role of tracheotomy in weaning. Chest 2001; 120(6):477-81.
20. Escarment J, Suppini A, Sallaberry M, et al. Percutaneous tracheostomy by forceps dilation: Report of 162 cases. Anaesthesia 2000;55(2):125-30.

21. Porter JM, Ivatury RR. Preferred route of tracheostomypercutaneous versus open at the bedside: A randomized, prospective study in the surgical intensive care unit. Am Surg 1999; 65(2):142-6.

22. Young D, Harrison DA, Cuthbertson BH, Rowan K; TracMan Collaborators. Effect of early vs late tracheostomy placement on survival in patients receiving mechanical ventilation: The TracMan randomized trial. JAMA 2013;309(20):2121-9.

23. Reilly PM, Sing RF, Giberson FA, et al. Hypercarbia during tracheostomy: A comparison of percutaneous endoscopic, percutaneous Doppler, and standard surgical tracheostomy. Intensive Care Med 1997;23(8):859-64.

24. Fikkers BG, van Veen JA, Kooloos JG et al. Emphysema and pneumothorax after percutaneous tracheostomy: Case reports and an anatomic study. Chest 2004;125(5):1805-14. 